'pondage' or moderate storage facilities can be economically developed to several times their continuous capacity in order to take the peak loads of fuel power systems. In Great Britain the Water Power Sources Committee reported in 1921 that there were 250,000 kilowatts of continuous power available. The modern view is that where small water-powers are used, they should be 'over-developed' by providing reservoirs so that they could take both the base loads and the peak loads. There are several electric-power schemes in America which take full advantage of the utility of the storage capacity of water-power in reservoirs when combined with steam stations.

\section{Science and Culture}

THE August issue of Science and Culture, published in Calcutta under the auspices of the Indian Science News Association as "a monthly journal of natural and cultural sciences", includes several important contributions and is in every way a credit to all who are concerned with its production. In the leading article on social implications of science, support is given for the movement represented by the committee on science and its social relationships of the International Council of Scientific Unions and the new Division of the British Association, and it is suggested that the Indian Science Congress Association should discuss the subject in a plenary session at the forthcoming meeting at Lahore. Sir James Jeans's lecture on the origin of the planets, delivered during the visit of delegates of the British Association to India, is published in the issue; and among the subjects of other interesting articles are: electrical charge distribution in thunderclouds, chemical composition and nutritive value of bananas, and recent advances in the study of plant growth hormones. The speeches made by Sir John Simon and Sir William Bragg at the anniversary dinner of the Royal Society on November 30, 1937, are reprinted in full from the Notes and Records of the Society, the first issue of which appeared in April last, together with notes on the foundation and history of the Society from the same publication.

\section{The late Lord Rutherford}

THE Transactions and Proceedings of the Royal Society of New Zealand, vol. 68, June 1938, contains an obituary notice and photograph of Lord Rutherford, signed "E. M.", doubtless the work of his old research student at Manchester, Dr. E. Marsden, who is now head of the N.Z. Department of Scientific and Industrial Research. There are about thirteen pages of biography written by one who well knew and admired Rutherford. Then follow nine pages of bibliography, listing about three hundred publications of books and papers by Lord Rutherford. This has been carefully compiled by Dr. C. M. Focken, Beverly-Mackenzie lecturer in physics at the University of Otago.

\section{Earthquakes in Italy and in New Zealand}

THE Central Office of Meteorology and Geophysics at Rome has recently issued its catalogue of macrosismi, or sensible earthquakes, for the year 1935 (Boll. Sismico, anno 1935). The total number known is 134, or about one third of the average number (412) for the forty years 1891-1930. Their intensity, also, was much less than usual; more than half were so slight that they were not able to shake doors or windows, and only one, with its origin in Etna, approached destructive strength, several houses in Acireale being slightly injured. The seismological section of the Dominion Observatory at Wellington has issued a somewhat less detailed report on the New Zealand earthquakes of 1936 (Bulletin No. 125; 1937). From this, we learn that the number of sensible earthquakes was 125 , less than half the average (264) for the preceding twelve years, but nearly the same as the average number (122) for the eight years excluding 1929-32, in which many after-shocks of the great earthquakes of 1929 and 1931 occurred. Five of the shocks were of intensity 6 (Rossi-Forel scale), that is, none could be ranked as a destructive earthquake. The epicentral regions (Buller River and Hawkes Bay) of the two earthquakes referred to seem to have resumed their normal activity.

\section{Renewed Seismic Actiyity in Greece}

Athens has again been disturbed by strong earth tremors but no damage has been done in that city. The epicentre of the shock is reported to have been to the north-east of the city, and is probably the same as that of July 20 and also July 27. The most recent shock was registered on seismograms in London at about 3 a.m. on September 18, and does not appear to have been any more intense than that of July 20 .

\section{Belgian Red Cross Exhibition}

THE Belgian Red Cross is organizing a popular scientific exhibition to be held in the Egmont Palace, Brussels, on October 1-30. It will be entitled "L'Homme" and will comprise the following groups : (1) movement (bones, muscles, nerves); (2) blood vessels and circulation; (3) respiration and voice; (4) foods and digestive organs; (5) thought and sensation; (6) special senses; (7) the part played by glands ; (8) transparent organs ; (9) the man of glass; (10) individual and public health. Further information can be obtained from Croix Rouge de Belgique, 80 rue de Livourne, Brussels.

\section{A Catalogue of Rare Books}

IN addition to works on English and European literature, the fine arts and a selection of important new books, a catalogue recently published by Bernard Quaritch, 11 Grafton Street, London, W.1, contains an annotated list of works on natural history including books from the library of Baron Bouck, early medicine and surgery from the library of Sion College, and the exact and applied sciences. Among the numerous works on natural history may be men. tioned the German text of J. Hübner's "Collection of Exotic Butterflies" (1806-1841) described as "an extremely fine and complete copy of the greatest 
entomological work ever produced," "Rippon's monograph on bird-wing butterflies (1898-1906), of which not more than thirty copies were completed, and Dresser and Sharpe's history of the birds of Europe (1871-1896). The most notable works on medicine and surgery in the catalogue are the first quarto edition of Sir Thomas Elyot's "Castel of Helth" (1541), the first edition of Gerard's "Herball or Generall Historie of Plantes" (1597) and the first edition of Harvey's "De Motu Cordis" (1628). A mong the old works on the exact and applied sciences figure the first edition of Cocker's "Arithmetik" (1678), Billingsley's translation of Euclid's 'Elements of Geometrie" (1570), Watson's translation of Bernard Palissy's "Learned Dialogue Concerning Waters and Fountaines" and Zahn's work on contemporary optics (1702).

\section{Speed Records}

ON September 15, the world's speed record on land was raised to $350 \cdot 2$ m.p.h. by Mr. John Cobb at the Bonneville Salt Flats, Utah. The car used was a 2,500 h.p. Napier-Railton. The previous record was $345 \cdot 59$ m.p.h. set up by Captain G. E. T. Eyston in his car Thunderbolt (see NATURe, Sept. 3, p. 430). On September 16, Captain Eyston regained the world record from Mr. Cobb with the Thunderbolt, attaining an average speed of 357.5 m.p.h. Sir Malcolm Campbell set up a water speed record of 130.91 m.p.h. on September 17 at Lake Hallwil, Switzerland, in his motor-boat Bluebird.

\section{North-East Coast Institution Engineering Awards}

THE Gold Medals of the North East-Coast Institution of Engineers and Shipbuilders given for papers read during the session have been awarded as follows : Engineering Gold Medal to G. J. Lugt, of the Werkspoor Company, Amsterdam, for his paper on "Diesel Varia"; Shipbuilding Gold Medal to Prof. F. Horn, of the Technische Hochschule, Berlin, for his paper on "Measurement of Wake"; M. C. James Gold Medal to Dr. T. Swinden for his paper on "Special Steels and their Application to Engineering and Shipbuilding". The Thomas Fenwick Reed Gold Medal, for the member of the Institution not more than thirty years of age who, among entrants for the medal, shows the greatest evidence of ability to take a share in the control of industry, has been awarded to John Hindmarsh. Mr. Hindmarsh was for some time in the employment of Michell Bearings, Ltd., before obtaining his Whitworth Scholarship, when he went to King's College, London; he is now employed by Messrs. Swan, Hunter and Wigham Richardson, Ltd., Neptune Works, Walker, Newcastle-on-Tyne. The Institution is giving two new scholarships this session (each of $£ 100$ ). These have been awarded to Harry Chilton, an apprentice of the North-Eastern Marine Engineering Co. (1938), Ltd., and a student at Sunderland Technical College ; and Thomas Corin, an apprentice ship draughtsman in the employment of Messrs. Swan, Hunter and Wigham Richardson, Ltd., Wallsend-on-Tyne, for study at King's College, Newcastle-on-Tyne.

\section{Announcements}

DURING the forthcoming winter, Mr. H. V. Garner, the guide demonstrator of the Rothamsted Experimental Station, and other members of the staff, will be available for lectures on the Rothamsted experiments to agricultural societies and similar bodies. All communications regarding lectures should be addressed to the Secretary, Rothamsted Experimental Station, Harpenden, Herts.

Prof. Alfred KÜHN, director of the KaiserWilhelm Institute of Biology, Berlin, Dr. Hugo Hassingen, professor of geography at the University of Vienna, and Dr. Hans Ahlmann, professor of geography at Stockholm, have been elected members of the Prussian Academy of Sciences in the physico. mathematical class.

The Child Welfare Information Centre of the League of Nations has issued a useful analysis of reports received by the Secretariat from thirty-seven countries on the legislative and administrative measures that have been taken or have been under consideration during the year May 1937 to May 1938 with reference to any aspect of child welfare (London: Allen and Unwin. 3s.).

The Child Guidance Council has awarded fellowships in psychiatry of the value of $£ 300$ and tenable for a year to Drs. Allen G. Crisp, Kenneth Soddy and Rosalind Vacher for half-time work at the London Child Guidance Clinic, 1 Canonbury Place, Islington, N.1.

The New York banker, Mr. W. Childs, has left Yale University ten million dollars for cancer research.

THIRTY radio coast stations of the United States are provided with a medical man to give advice to passing ships.

THE London County Council has accepted a tender for $£ 72,135$ for building work in connexion with the erection of its new antitoxin establishment at Carshalton, which will afford valuable opportunities for research.

THE Ministry of Health with the collaboration of the Department of Health for Scotland and the National Fitness Council has arranged a permanent Health Exhibition which is being shown at the British Empire Exhibition and will be sent on to towns throughout Great Britain.

THE sixth Argentine Congress of Medicine, which will be held at Cordoba on Oetober 16-21, will consist of three sections devoted respectively to biology, internal medicine and surgery.

ThE twenty-fifth French Congress of Social Hygiene will be held at the Bordeaux Faculty of Medicine on September 30-October 2 under the presidency of M. Georges Risler. Further information can be obtained from Alliance d'hygiène sociale, 5 rue des Cases, Paris. 